\title{
Plants used in Iraqi traditional medicine in Erbil - Kurdistan region
}

\section{Alaadin Naqishbandi *}

Abstract
Background and objective: Herbal medicine is a traditional or folk medicine practice
based on the use of plants' seeds, berries, roots, leaves, barks, flowers and plant extracts for medicinal purposes. This survey highlights the traditional phytotherapy practices by traditional healers of Erbil-Kurdistan region in the treatment of various disorders.

Methods: An ethnobotanical survey was undertaken to collect information from traditional healers on the use of medicinal plants in Erbil-Kurdistan region. The indigenous knowledge of local traditional healers and the native plants used for medicinal purposes were collected through questionnaire and personal interviews.

Results: The investigation revealed that the traditional healers were not professionally authorized and 32 plants belonging to 23 families were used to treat various diseases in traditional medicine. The plants reported have been identified and presented in a table with the vernacular names, useful parts, dosage preparations and medicinal uses.

Conclusion: Many recorded species of plants are used in Erbil- Kurdistan region in traditional medicine but lack phyto-therapeutic evidence. Most indigenous plants remain to be studied which may yield many exciting data for further investigation.

Keywords: Survey, medicinal plants, Erbil, Kurdistan.

\section{Introduction}

Herbal medicine is a traditional or folk medicine practice based on the use of plants' seeds, berries, roots, leaves, bark, flowers and plant extracts for medicinal purposes. ${ }^{1}$ Plants are important sources of medicine for thousands of years and are the most important source of life saving drugs for majority of the worlds' population. ${ }^{2}$ Herbal remedies are widely used for the treatment and prevention of various diseases that contain highly active pharmacological compounds. ${ }^{3}$ The knowledge about medicinal plant among the people of Iraq is based on hundreds of years of belief, observations, and a rich medicinal history. ${ }^{4-6}$ This survey highlights the phytotherapy practices by traditional medicine in the treatment of various disorders in Erbil-Kurdistan region.

\section{Methods}

The study was performed during the period from June $1^{\text {st }}, 2011$ to June $1^{\text {st }}, 2012$. The Survey included 10 traditional healers in Erbil, Kurdistan region, Iraq. The formulary of the survey included two lists of questionnaires. ${ }^{7}$ The first one included information about the traditional healers including the address, age, sex, duration of practicing herbal medicine and educational level. The second questionnaire included information about using medicinal plants by traditional healers including plant botanical and vernacular name, part used, form of use and therapeutical use. Anonymity of the participants was ensured. After compilation of all the data, plant materials were collected. Determination of the botanical names of the plants was done in collaboration with Biology Department, College of Education, Salahaddin University. A voucher specimen of each plant has been deposited at the Department of Pharmacognosy, College of Pharmacy, Hawler Medical University.

* Department of pharmaceutcal, College of Pharmacy, Hawler Medical University, Erbil, Iraq. 


\section{Results}

The traditional healers participated in this survey were males between 34 and 46 years old. The duration of their experience as traditional healers using medicinal plants varied between 10 and 25 years. Neither any one of the traditional healers was found to be graduated from specialized academic institutions of herbal medicine nor having participated in training courses prepared by authorized institutions of herbal medicine. The educational level of the traditional healers varied as Bachelor of art holders, diploma from institute for preparation of imams and preachers, and primary school certificate holders. Furthermore, no traditional healer location in which they were practicing herbal treatment was authorized by an official health authority. Additionally, the information collected in the questionnaire about dispensing herbal drugs were recorded and tabulated (Table 1 ).

Table 1: Plants used in traditional medicine in Erbil- Kurdistan region

\begin{tabular}{|c|c|c|c|}
\hline Botanical and Vernacular Names & Part used & Preparation & Medicinal Indications \\
\hline $\begin{array}{l}\text { Adiantum capillus- veneris } \\
\text { (Adiantaceae), Kaetaran }\end{array}$ & LE & Decoction & $\begin{array}{l}\text { Nephritis, Renal stone, Allergy, Preventing } \\
\text { hair loss, Hypertension }\end{array}$ \\
\hline Allium cepa (Liliaceae), Pewaz & $\mathrm{BU}$ & Decoction & $\begin{array}{l}\text { Antioxidant, Enhancing immune defense, } \\
\text { Reduce risk of infection }\end{array}$ \\
\hline Allium sativum (Liliaceae), Seer & $\mathrm{BU}$ & Decoction & $\begin{array}{l}\text { Hypertension, Hypercholesterolemia, } \\
\text { Common cold, Antibacterial, Anticancer, } \\
\text { Enhancing immunity }\end{array}$ \\
\hline $\begin{array}{l}\text { Andropogon sorghum(Gramineae ), } \\
\text { Reshale Ganmashame }\end{array}$ & Cornsilk & Decoction & Cystitis, Nephritis \\
\hline $\begin{array}{l}\text { Anethum graveolens } \\
\text { (Umbelliferae), Shweet }\end{array}$ & LE & $\begin{array}{l}\text { Decoction, } \\
\text { Powdered in } \\
\text { capsule }\end{array}$ & Hypercholesterolemia \\
\hline $\begin{array}{l}\text { Anthemis nobilis } \\
\text { (Asteraceae), Gula Hajela }\end{array}$ & $\mathrm{FL}$ & $\begin{array}{l}\text { Infusion, } \\
\text { Inhalation, } \\
\text { soap }\end{array}$ & $\begin{array}{l}\text { Common cold, Antitussive, Reducing body } \\
\text { temperature, Bronchitis, sinusitis, Sore } \\
\text { throat, Hair tonic, Cleaning and opening } \\
\text { pores of skin, healing of wounds, Acne }\end{array}$ \\
\hline $\begin{array}{l}\text { Artemisia campestris } \\
\text { (Compositae), Sheeh }\end{array}$ & AP & $\begin{array}{l}\text { Decoction, } \\
\text { powdered in } \\
\text { capsule }\end{array}$ & $\begin{array}{l}\text { Hypercholesterolemia, Hypoglycemic Tonic } \\
\text { for body, Analgesic Anthelmintic }\end{array}$ \\
\hline $\begin{array}{l}\text { Calendula officinalis } \\
\text { (Asteraceae), Hamish Baha }\end{array}$ & LE & Decoction & $\begin{array}{l}\text { Peptic ulcer, Appetizer, Regulation of } \\
\text { menstrual cycle }\end{array}$ \\
\hline $\begin{array}{l}\text { Cassia acutifolia } \\
\text { (Fabaceae), Senamake }\end{array}$ & LE & Infusion & Hemorrhoid, Laxative \\
\hline $\begin{array}{l}\text { Cichorium intybus } \\
\text { (Compositae), Jakjaka }\end{array}$ & AP & Decoction & $\begin{array}{l}\text { Blood purification, Hypercholesterolemia, } \\
\text { Hypoglycemic, Hypertension, Allergy, UTI }\end{array}$ \\
\hline $\begin{array}{l}\text { Cinnamomum zeylanicum } \\
\text { (Lauracae), Darjeen }\end{array}$ & BA & Decoction & $\begin{array}{l}\text { Antibacterial, General tonic, Diuretic, Renal } \\
\text { failure, Anemia, Sexual tonic for men }\end{array}$ \\
\hline $\begin{array}{l}\text { Citrus aurantifolia } \\
\text { (Rutaceae), Lemo Basre }\end{array}$ & FR & Decoction & $\begin{array}{l}\text { Tonic , Useful for kidney, liver, spleen and } \\
\text { heart diseases, Diuretic }\end{array}$ \\
\hline $\begin{array}{l}\text { Citrus limonum } \\
\text { (Rotaceae), Lemo }\end{array}$ & FR & Decoction & Renal stone \\
\hline $\begin{array}{l}\text { Commiphora myrrha } \\
\text { (Burseraceae), Bneshta tal }\end{array}$ & Gum & Decoction & Peptic ulcer, Laxative \\
\hline $\begin{array}{l}\text { Corcus sativus } \\
\text { (Iridaceae), Zafaran }\end{array}$ & FL & Infusion & $\begin{array}{l}\text { Dyspepsia, Delaying menstrual cycle, } \\
\text { Arthritis }\end{array}$ \\
\hline
\end{tabular}




\section{Table (1) Continued}

Botanical and Vernacular Names

Coriandrum sativum

(Umbeliferae), Kazbara

Cuminum cyminum

(Apiaceae), Zeera

Cyperus rotundus

(Cyperaceae), Sotka

Dianthus caryophyllus

(Myrtacea), Karanfl

Eurca sativa

(Brassicaceae), Jarjer

Glycyrrhiza glabra

(Fabaceae), Balak

Lavender angustifolia

(Lamiaceae), Khuzame

Nigella sativa

(Ranunculaceae), Rashka

Pimpinella anisum

(Umbelliferae), Yansun

Punica granatum

(Punicaceae), Hanar

Quercus persica

(Fagaceae), Baru

Rheum ribes

(Polygonaceae), Rewas

Rubia tinctorium

(Rubiaceae), Fua

Salvia officinalis

( Lamiaceae), Gula Mariam

Thymus vulgaris

(Lamiaceae), Jatra

Trigonella foenum-graecum (Leguminosae), Shmle

Zingiber officinale

( Zingiberaceae), Zanjafel
Part used Preparation

FR

Decoction

Decoction,

Powdered in

capsules

RO

Decoction, ointment

AP

Decoction

AP

RO

Decoction ointment

Decoction

FL Infusion

SD

Decoction

SD

Decoction

FP

Decoction

FR

Decoction

RO

$\mathrm{RO}$

FL

LE

SD

Decoction, ointment

$\mathrm{RH}$ capsule

Decoction

\section{Medicinal Indications}

GIT and UT diseases

Colitis, Regulating of menstrual cycle, Hairsutism, Promote lactation, Carminative

Flatulence, Nausea and vomiting, Regulating hormones (prolactin), Tonic, Hypoglycemic, Diuretic, Hemorrhoid and anal fissure

General tonic, Sexual tonic, Local anesthetic

Hypoglycemic, Skin diseases, Prevent baldness

Rheumatic disorder, Allergy, Dyspepsia, Peptic ulcer, General tonic,

Cough and bronchitis, Hypoglycemia, Laxative, Asthma

Asthma, bronchitis, indigestion, Hypertension, Hypercholesterolemia

Repelling gases, Antibacterial, Antiviral, Sexual tonic, Enhance memory, Tonic, Allergy, Enhance immune system, Bronchitis, asthma

Flu, cough, Diuretic, Analgesic, Indigestion, flatulence, Anxiety

Inflammation of oral cavity, Inflammation of skin, Peptic ulcer, Antifungal

General tonic, Constipation, Colitis, Severe diarrhea, Gastritis, Hemorrhoid

Powdered in Hypertension, hypoglycemic

Diuretic, Tonic for the hair, Liver and urinary tract diseases

Regulate menstrual cycle, Hypoglycemic, Hypercholesterolemia, Flatulence, Antibacterial, Fever

Gingivitis, Dyspepsia, Appetizer, Abdominal cramps, Antifungal, Anthelmintic, Expectorant, Tonic, Enhance immune system, Cystitis and nephritis

Inflammation of skin, Irritable bowel Appetizer, Hypoglycemic, Diuretic, Stimulate lactation, Sexual tonic in women, UTI , Renal stone

Hypercholesterolemia, Sexual tonic, Regulate blood circulation, Hemorrhoid Stomach and respiratory problems

AP, aerial part; LE, leave; FL, flower; FR, fruit; SD, seed; RH, rhizome; RO, root; BU, bulb; BA, bark 


\section{Discussion}

The survey work has yielded 32 plants belonging to 23 families which are used by the traditional healers as medicinal plants in Erbil-Kurdistan region. The study revealed that the educational levels of the herbal practitioners were variable, most of their scientific backgrounds did not have relation to their jobs as traditional healers but got their information either through reading books about herbal medicine or they learned the work through their ancestors. It seems that many popular plants have been used long time for internal disorders like Allium sativum, Anthemis nobilis, and Pimpinella anisum for treating of common cold, Cuminum cyminum and Thymus vulgaris as a carminative remedy. However, many other uses seem to be reported for the first time. Some of plants indicated by the traditional healers were approved scientifically, for instance Glycyrrhiza glabra with anti allergic properties. It has been suggested that the anti allergic effects are mainly due to glycyrrhizin, $18 \beta$-glycyrrhetinic acid, and liquiritigenin which can relieve IgE-induced allergic diseases such as dermatitis and asthma. ${ }^{8}$ The anti-inflammatory and anti-arthritis has also been recorded previously. ${ }^{9}$ In the same time, some indications were not in agreement with that in the literature such as using Glycyrrhiza glabra for treating of hypoglycemia. Literature review on Nigella sativa has showed that the plant is used for allergy conditions, asthma, strengthening the immune system, and it has antiviral and antibacterial action. ${ }^{10}$ These indications were compatible with what the practitioner indicated. In the same time, Trigonella foenum-graecum seed is scientifically approved to be used to reduce blood glucose level and cholesterol level, it also stimulates lactation. ${ }^{11-12}$ The traditional use of Corcus sativus for the treatment of arthritis is supported by research studies that recorded the antioxidant, antinociceptive and anti-inflammatory activities of aqueous and ethanolic extracts of Corcus sativus stigma and petal. ${ }^{13-14}$

\section{Conclusion}

There are medicinal plant remedies to treat a wide range of illnesses, as curatives or palliatives to many health problems. Many recorded species of plants are used in Erbil - Kurdistan region in traditional medicine but lack phyto-therapeutic evidence. It is necessary to perform more phytochemical and pharmacological studies to explore the potentiality of plants used for medicinal purposes.

\section{Conflicts of interest}

The author reports no conflicts of interest.

\section{References}

1. Kraft K. Complementary/Alternative Medicine in the context of prevention of disease and maintenance of health. Prev Med 2009; 49(2):88-99.

2. Leena T, Jaindra NT. Role of biotechnology in medicinal plants. Trop J Pharm Res 2003; 2(2):243-53.

3. Saad B, Azaizeh H, Abu Hijleh G, Said O. Safety of traditional Arab herbal medicine. eCAM 2006; 3:433-9

4. Alsamarkandi NA. Principles of Drugs Composition (Esool Tarkeeb Aladwaii)- Investigated by Neglai Fathi. Baghdad: University of Baghdad Publication (Center for the Revival of Arab Scientific Heritage); 1985. p.23-46.

5. Avicenna. Law in Medicine (Alkanoon Fe Aldheb). Beirut: Al-Maaref Library Publications; 1980. p.260-72

6. Khalil Y. Old Arab Medicine and Pharmacy. Baghdad university Library publication; 1979. p. 9-57.

7. Jouad $H$, Haloui $M$, Rhiouani $H$, El Hilaly J, Eddouks M. Ethnobotanical survey of medicinal plants used for the treatment of diabetes, cardiac and renal diseases in the North centre region of Morocco (Fez-Boulemane). J Ethnopharmacol 200; 77:175-82.

8. Shin YW, Bae EA, Lee B, Lee SH, Kim JA, Kim $Y S$, et al. In vitro and in vivo antiallergic effects of Glycyrrhiza glabra and its components. Planta Med 2007; 73(3):257-61.

9. Racková L, Jancinová $V$, Petríková $M$, Drábiková $K$, Nosál $R$, Stefek $M$, et al. Mechanism of anti-inflammatory action of liquorice extract and glycyrrhizin. Nat Prod Res 2007; 21(14):1234-41.

10. Schleicher $P$, Saleh $M$. Black Cumin. The magical egyptian herb for allergies, asthma and immune disorders. Vermont: Healing arts press; 2000.

11. Phyllis A. Prescription for herbal healing: an easy-to-use A-to- $Z$ reference to hundreds of common disorders and their herbal remedies. $1^{\text {st }}$ 
ed. New York: Avery; 2002.

12. Sayed Z N, Deo R, Mukundan U. Herbal remedies used by Warlis of Dahanu to induce lactation in nursing mothers. India Journal of traditional medicine 2007; 6 (4):606-10.

13. Pomaa A, Fontecchioa G, Carluccib G, Chichiricc G. Anti-Inflammatory Properties of Drugs from Saffron crocus. Antiinflamm Antiallergy Agents Med Chem 2012; 11 (1):37-51.

14. Hosseinzadeh $\mathrm{H}$, Younesi HM. Antinociceptive and anti-inflammatory effects of Crocus sativus $L$. stigma and petal extracts in mice. BMC Pharmacology 2002; 2(7):1-8. 